\title{
THE METHOD OF SYMBOLIC INTERPRETATION OF GRIGORY SKOVORODA
}

For a long time Grigory Savich Skovoroda (1722-1794) attracted the interest of his contemporaries and many later historians primarily by his life. Such an interest seems to be a little strange, since at first glance he did not have a very eventful life. He was born at the end of 1722 in the Ukraine in the family of a Cossack with little land. This was the time of gradual elimination of the Hetman's political autonomy. The Ukraine was becoming a regular province of the Russian Empire. But the Cossacks still continued to maintain their personal freedom. One of the consequences of such freedom was the opportunity to receive an education. A widespread network of village schools existed in the Ukraine at the time. Further education could be continued in a seminary. The institution of higher education at that time was the Kiev-Mohyla Academy. In all types of schools teaching was provided by local clergy. Education in village schools was conducted in Ukrainian, and at the Academy it was conducted in Latin. Upon graduation from the village school in 1734, Skovoroda entered the Kiev-Mohyla Academy where he studied intermittently until 1753. The Kiev Academy at the time provided both higher and secondary education, so that the usual period of study in the Academy was 10 years. Skovoroda finished four lower classes (preparatory class fara, lowest class infima, grammar, and syntax) and six higher classes (poetics, rhetorics, philosophy, and theology). However, Skovoroda did not want to become a clergyman and did not complete his education in the final year. According to the unanimous opinion of his biographers, Skovoroda was the best student of the Academy, and he particularly succeeded in theology. Concerning the education provided by the Kiev Academy, historians note a scholastic type of learning. Education was based on the model of Jesuit colleges which were also the source of courses and textbooks. The Academy prepared preachers and polemicists who were supposed to protect the authority of the Church by their skillful use of quotations and rhetorical devices. The Academy did not provide a 
thorough philosophical education and was even less concerned with the development of critical thinking in its students. The studies were focused on practical philosophy associated with ethics and politics. The Academy produced rigorists and doctrinarians aimed at achieving a successful Church career. From the well-known figures of the time who taught Skovoroda we can only name George Konissky who gave courses in poetics and philosophy at the Academy, emphasizing the moralizing aspect in his teaching. The teachers of the Academy, including Konissky, often combined scholarship with literary writing. This manner was also adopted by Skovoroda. He learned well the subjects which were taught at the Academy and during his whole life he faithfully continued the traditions of the Kiev-Mohyla Academy. In 1742 he moved to St. Petersburg and became a singer in the choir of the Court chapel. After staying for two and a half years in the capital city, Skovoroda returned to Kiev in order to complete his education, but in 1745 left for Hungary as a part of the mission of General Vishnevsky. The purpose of the mission was the purchase of Tokaj wines for the tsar's court. Skovoroda also had to carry out the duties of a clerk at an Orthodox church which was at the mission. Skovoroda stayed abroad until 1750. He visited the neighboring lands, including Vienna, but more detailed information about his stay abroad as well as about his life in St. Petersburg has not been preserved. Skovoroda himself never alluded to it. When he returned to the Ukraine, he started teaching. In 1750-1751 he taught poetics in the Pereyaslav seminary. From 1755 to 1759 as a home teacher Skovoroda lived on the estate of the landlord S. Tomara. From 1759-1769 Skovoroda intermittently taught ethics, poetics, Greek and Latin in the Kharkov Collegium. During these years he wrote his first works. From 1769 until his death in 1794, he led the life of a wanderer. At that time he wrote his major works - the philosophical and religious dialogues with didactic contents. A circle of admirers, belonging to various social classes formed around Skovoroda; they shared a love for moral instructions which he would willingly give. They, in turn, provided their "teacher" with shelter, fed him and supported him. Thus Skovoroda was remembered by his friends in the first place as a teacher of life and spiritual mentor.

The favorite disciple and friend of Skovoroda as well as his first biographer, Mikhail Kovalinsky, describes the spiritual outlook of his teacher in the following way, "His spirit removed him from all attachments and making him a stranger, a wanderer and roamer, it produced in him the heart of a citizen of the world, who has no relatives, no pos- 
sessions, no corner where to lay his head, but enjoys a hundredfold more pleasures of nature, pleasures simple, innocent, unconcerned, true, gathered by a clean mind and untroubled spirit among the treasures of the eternal."1 Such way of life was caused by his special attitude toward life and its understanding. First of all, Skovoroda understood life as religious service and the search for divine truth, "I know for sure that I have completely devoted myself to the divine truth." ${ }^{2}$ His favorite way of life, often practiced by Skovoroda, was the path of journey or traveling. He would repeatedly say, "Our life is a journey." 3

The most striking quality of Skovoroda for his contemporaries and historians was his literal adherence to his chosen ideals, the oneness of his life and his teaching. At the same time his entire behavior shows some kind of archaism, not of his time. Skovoroda combines simultaneously traditionalism and education. He lives in St. Petersburg, travels across Europe, and then goes over to join the guild of wandering paupers, the bearers of folk wisdom. In the last period of his life - the time of wandering - his life was not so much the learning of the truth and not even his favorite self-knowledge as much as the demonstration of his principles. The priority of the spiritual world in theory turned into disdain and rejection of real life in practice. Alienation from the world took the form of extreme asceticism with the features of foolishness for Christ, manifested through the simplification of life. Skovoroda himself emphasizes the positive role of foolishness for Christ in his dialogue "Askhan:" "This foolishness that Paul mentions in the 'Corinthians.' (cf. 1 Cor. 4:10). Open the veil and you will see that it is the wisest, and it is only hid itself behind foolishness." 4 The behavioral archetype of foolishness for Christ, wandering, simulation of the good life as well as rejection of the world and asceticism turned Skovoroda's life into "God's foolishness," 5 which allowed Vladimir Ern to compare Skovoroda's life to the Franciscan way of life, "Skovoroda resorted to the Franciscan model of life. He did not sow nor reap, and in the name

(1) М. И. КовадинскиЙ, “Жизнь Григория Сковороды” [The Life of Grigory Skovoroda], in Г. С. СковородА, Сочинения [Writings], т. 2, Москва, 1973, c. 378.

(2) Г. С. Сковорода, Сочинения, т. 2, Москва, 1973, с. 212 (Letter to M. I. Kovalinsky).

(3) Ibid., т. 1, c. 287, 452.

(4) Ibid., c. 224.

(5) Ibid., c. 243. 
of the Lord, in the name of wisdom, enjoyed the blessings which his friends, his admirers, and many people had given him, marveling with a good feeling at his unusual, eccentric, but at the same time righteous life." ${ }^{\prime 6}$

A heretical teaching of spiritual Christianity which was close in form to Protestantism was spreading in those years in the south of Russia, and contributed to the popularity of Skovoroda's life and teaching. The propagation center of this heresy was precisely the Kharkov Guberniya, where Skovoroda did most of his travels. The proximity of life and spiritual ideals preached by Skovoroda, led to the fact that against his will he turned out to be a fellow-thinker of the sectarians. We should particularly emphasize the closeness of his views with the teaching of the sect of the Doukhobors.

Skovoroda's literary heritage can be divided into four groups: above all there are his philosophical and theological works, then follow his literary works - poems, songs, fables, letters and, finally, translations. The literary works were mainly written in the earlier period of his life, the period of teaching, although some of them were written at the time when Skovoroda already started leading his wandering life. His poetical works were partially collected in the book "Garden of divine songs," and fables in the book, "Kharkov Fables." These works of Skovoroda had practically no effect on the development of Ukrainian and Russian literature, although some of them were popular among simple people.

His philosophical and theological views were expressed in his treatises, dialogues, and fables; the following works have survived: "Initial door to Christian good-naturedness" (chronologically the earliest treatise written by Skovoroda when he was a teacher at the Kharkov Collegium), "Narcissus," "Symphony, entitled the book of Askhan, about knowing thyself," "Conversation, entitled two, that it is easy to be blessed," "Conversation One. Entitled Observatorium (Zion)," "Conversation Two. Entitled Observatorium specula, in Hebrew - Zion," "Dialogue about the ancient world," "Conversation among five travelers about life's true happiness (friendly conversation about the peace of the soul)," "The Ring," "Conversation, called the alphabet, or the abecedarium of the world," "Little book called silenus alcibiadis, that is to say, Alkiviades' icon (the serpent of Israel)," "Little book about the

(6) В. Эрн, Григорий Саввич Сковорода. Жизнь и учение [Grigory Savvich Skovoroda. Life and teaching], Москва, 1912, с. 146. 
reading of Holy Scripture, entitled the wife of Lot," "Debate of Archangel Michael with Satan about this: is it easy to be good," "Debate of a demon with Barsabas," "Grateful Erodius," "Poor lark," "Dialogue. Its name is serpent's flood." A number of Skovoroda's letters also touch upon philosophical issues. Skovoroda also translated the dialogue of Cicero "On Old Age," as well as five "Moralia" of Plutarch, of which only one, "On the silence of the heart," has survived.

It is difficult to say when Skovoroda's views took a definite shape; at least, it is difficult to discern any evolution of ideas in his writings. All his treatises and dialogues are devoted to the same topics; they postulate the same positions and support them with the same arguments and examples. It is worth noting the aphoristic manner of style and the ornateness of language in his works, relating to the prophetic manner of philosophizing, announcing rather than investigating the truth.

Skovoroda did not publish any of his writings during his lifetime. They circulated as handwritten copies among his admirers, which was the common practice of the time. His first work appeared in print anonymously at the very end of the eighteenth century. After that, in 1806, the masons' magazine, "Sionsky Vestnik" ("The Messenger of Zion") published another writing of Skovoroda. It should be noted that some thoughts of Skovoroda were close to the views of the masons; a series of dialogues also contains Masonic symbolism. A selection of Skovoroda's poems and fables was published in the early 1860s. The philosophical works of Skovoroda started to be published only at the end of the nineteenth century upon the hundred year anniversary of his death. The edition was prepared by a member of the Academy of Sciences Dmitry Bagalei, who published previously unknown philosophical and theological treatises and dialogues of Skovoroda. Then for the first time Skovoroda received recognition as a philosopher. The reason for this was the fact that the publication of his writings coincided with one of the first attempts to write the history of Russian philosophy and to produce a comprehensive view on the development and dissemination of philosophy in Russia. Skovoroda happened to be just what was needed for that. His independent isolated position, according to the historians, was meant to emphasize his philosophical independence and to fill the insufficiently studied philosophy of the eighteenth century. Vladimir Ern played an important role in the promotion and propagation of Skovoroda's views. In a series of articles written in the beginning of the twentieth century and 
in his book "Grigory Savich Skovoroda. Life and Teaching" published in 1912, Vladimir Ern introduced the ideas of Skovoroda in such a way that they turned out to be in tune with the philosophical and religious quests of Russian thinkers of the late nineteenth - early twentieth century. Being himself a gifted philosopher, Ern saw in Skovoroda what he wanted to see and rather ascribed Skovoroda his own views, pointing to pre-eminent anthropologism of Skovoroda's philosophy. It was Ern who reintroduced the expression "Russian Socrates," which was coined back in 1835 by one of the first researchers of Skovoroda, Alexander Hasdeu, and which would later constantly follow the name of Skovoroda.

In the same years, in the series, "Materials on the history of Russian sectarianism," Vladimir Bonch-Bruevich published the first volume of collected works by Skovoroda. Due to external circumstances, that was the only volume published. However, in the future this publication has played a cruel joke on Skovoroda. His publisher Vladimir BonchBruevich was a friend of Vladimir Lenin; after the October Revolution he held high posts in the government of the Bolsheviks. We owe the ideological canonization of Skovoroda in Soviet historiography to his efforts. Skovoroda was included in the "Plan of monumental propaganda," signed by Lenin, which led to the official sanctioning of Soviet research on Skovoroda's thought.

At the same time the intellectuals, including both Ukrainian historians (Chizhevsky, Mirchuk), and Russian historians (Zenkovsky, Bobrinsky), who emigrated after the civil war also called to mind the thinking of Skovoroda. They faced a similar task - to give a comprehensive picture of Russian (or Ukrainian) philosophy. It is clear that their interpretation of Skovoroda's philosophy had radical differences from the interpretation of the Soviet historians of philosophy. The same statements of Skovoroda were understood in the completely opposite way. Both Soviet and emigrant scholars were in some way ideologically engaged. Thus, for example, in his attempts to compose the history of Ukrainian philosophy, Dmitry Chizhevsky had to excessively exalt the value of Skovoroda as a thinker. On the one hand, Chizhevsky was trying to trace the relationship of Skovoroda's ideas with the tradition of German mysticism, and on the other, the more dubious relationship of antinomianism of Skovoroda's writing style (as he interpreted the dualism of views and aphoristic style) with the German idealist philosophy. However, the fact that Skovoroda was a contemporary of Kant, does not make him a Kantian. The results of his 
research were summarized in a book which Chizhevsky published in 1934 in Warsaw. ${ }^{7}$

In the two-volume "History of Russian Philosophy" - still one of the best studies on the subject - Vassily Zenkovsky tried to present such an evolution of the philosophical ideas of the Russian thinkers, where their religious views would play a decisive role. This intention involuntarily coincided with how Skovoroda himself understood his life purpose. Zenkovsky described Skovoroda as a Christian, even a Biblical thinker who saw practical didactic purpose in his philosophy and understood it as "the teaching of good." Gustav Shpet characterized Skovoroda's thought in a very accurate although sharp way in his "Essay on the development of Russian philosophy," published in Petrograd in 1923. Shpet pointed to the moral and not philosophical significance of Skovoroda's legacy. Shpet wrote, "From start to finish, Skovoroda is a moralist. It is neither science nor philosophy, which dominate his thoughts, but only his search for a path to happiness and bliss for himself and pointing this path to others."

Ukrainian scholars wrote about Skovoroda most extensively both in Soviet Russia and in the emigration. The most complete edition of his writings, written in Ukrainian, appeared in the 1960s in Kiev. In 1973, this two-volume edition with small additions was published in Russian for the 250th anniversary of Skovoroda's birth. The amount of studies on Skovoroda rose sharply because of the anniversary. However, neither these studies nor the subsequent publications added diversity to the evaluation of his work. Skovoroda was still interpreted as a peasant democrat and educator of simple people. ${ }^{9}$ His "foolishness" and simplification were understood as democratism, his moral teaching and preaching were understood as attempts at enlightenment of the people, and his criticism of the official Church, close to sectarianism, was understood as anticlericalism. In this sense, the typical as-

(7) Д. ЧиЖевСКий, Философия Г. С. Сковородъ [Philosophy of G. S. Skovoroda], Варшава, 1934.

(8) Г. Г. ШПЕт, “Очерк развития русской философии” [Essay on the development of Russian philosophy], in А. И. ВВедЕНСКИЙ, А. Ф. Лосев, Э. А. РАдАов, Г. Г. ШПет, Русская философия [Russian philosophy], Свердловск, 1991, c. 295.

(9) See, for example, П. С. Шкуринов, Мировоззрение Г. С. Сковороды [Worldview of G. S. Skovoroda], Москва, 1962; Ірем, Философия России XVIII в. [Philosophy of Russia in the eighteenth century], Москва, 1992. 
sessment of the Soviet researchers of Skovoroda's philosophy can be seen in the following statement by I. A. Tabachnikov, "Still true democratism, humanism, enlightenment, and militant anticlericalism always took precedence in his world." 10

A new understanding of the philosophy of Skovoroda started to emerge already at the end of the Soviet era and is reflected in the book of Yu. Ya. Barabash. ${ }^{11}$ The thought of Skovoroda became the starting point for the nationalist-oriented emerging Ukrainian philosophy. The book by a Kiev philosopher, M.V. Popovich, was written from this perspective. ${ }^{12}$ The most significant study on Skovoroda's teaching should be considered to be a book by L. A. Sofronova. ${ }^{13}$

Discrepant views concerning Skovoroda emerged already during his lifetime. On the one hand, there were admirers who fed and supported Skovoroda; on the other hand there was the official Church and the authorities. They did not encourage his way of life, but did not persecute him for anti-social behavior. In fact, there was nothing out of the ordinary in the behavior of Skovoroda. He belonged to a particular social group of wandering almsmen who earned their living by singing, telling moralizing stories and fables, or retelling Biblical parables. The difference between Skovoroda and an ordinary pious dependant was that Skovoroda was educated, knew several languages, wrote down and circulated his works. The best work on Skovoroda is, still, perhaps the very first description of his life by Kovalinsky, composed shortly after the death of Skovoroda. It is written with love and captures the life of the wandering thinker, which embodied his philosophy in the most complete way.

Grigory Skovoroda stands out in the history of Russian religious and philosophical thought. As a philosopher, Skovoroda was discovered only in the late nineteenth century when his ideas became consonant with the spiritual quest of the Russian intellectuals. The philosophy of Skovoroda cannot be defined solely by anthropologism,

(10) И. А. ТАБАЧников, Григорий Сковорода [Grigory Skovoroda], Москва, 1972, c. 11.

(11) Ю. Я. БАРАБАШ, “Знаю человека...": Григорий Скорода: Поэзия. Философия. Жизнь ["I know the man...": Grigory Skovoroda: Poetry, Philosophy. Life], Москва, 1989.

(12) М. В. Попович, Григорій Сковорода: філософія свободи [Grigory Skovoroda: Philosophy of Freedom], Киев, 2007.

(13) Л. А. СофроновА, Три мира Григория Сковороды [Three worlds of Grigory Skovoroda], Москва, 2002. 
moralism, or Biblical knowledge combined with mysticism. The key to his philosophy is the method of symbolic exegesis. Particular instances when Skovoroda applies this method to various fields lead to anthropologism, moralism, or criticism of the official Church life. The method of symbolic exegesis underlies specific features of his ontology, epistemology, and the dualism of the world and morality. In turn, symbolic exegesis is associated with his perception and understanding of the Bible and with his personal religious life. However, we should note that the method of Skovoroda has several levels. First of all, it is the way the author constructs his writings, the logic of exposition and presentation of his work. It is also the method of working with the material or problem, the method Skovoroda used for understanding the problem or the method of understanding which forms the way of seeing the subject and ways of disclosing the problem. The method of symbolic exegesis belongs to this second level. The value of this method was already noticed and highly evaluated by Vladimir Ern, "The entire outstanding, revolutionary innovation of Skovoroda can be summarized in a single phrase: He consciously returned serious meaning to the symbol and made symbol of one of the central categories of his philosophizing." 14

We should briefly describe the first aspect of the method, which leads directly to the second. First of all, the aphoristic character of the style with which Skovoroda's works were written is striking. Aphorism, representing the art of interpretation, at the same time is what ought to be interpreted. Interpretation reveals the particular, fragmentary meaning of a phenomenon by explaining only one isolated subject. Thematic discreteness of Skovoroda's philosophy is obvious: selfknowledge, moral perfection, ontological dualism. The main points of his writings, expressed in an aphoristic form, are enveloped in quotations from Scripture and retellings of episodes from ancient history which not as much explain and expand a thought, as obscure and veil it. This provoked a rightful reproach of one of the heroes in the Dialogue, "Conversation One. Entitled Observatorium (Zion)": "I see that your guardian angel is the angel of grandiloquence." ${ }^{15}$ It seems as if the author is afraid of the thought which he declared himself, and tries to swaddle and hide it in trustworthy and commonly accepted references

(14) Эрн, Григорий Саввич Сковорода, с. 223.

(15) СковородА, Сочинения, т. 1, с. 278. 
and images. This approach requires, above all, faith in the declared positions rather than proofs and understanding.

The argument being constructed on the principle of "nothing else, but...," inevitably leads to the fact that the proof is replaced by an illustration, "I will portray this with your likeness." ${ }^{16}$ Favorite examples which Skovoroda sometimes borrowed from the Bible and sometimes created himself, were intended to illustrate one of his theses. The moralizing attitude of Skovoroda's thought regularly took forms, inherent in the didactic genre, which he expanded not only onto poetry, but also onto philosophy. Yet, according to Skovoroda, in addition to direct moralizing enclosed in the parable it should demonstrate the double-layer structure of existence, disclose true hints and true meanings hidden behind a visible aspect. "You need to watch, to behold and to recover your sight, to touch and to think, to see and to understand. Colorful shadow meets your eye, and the dream should shine in your mind; the appearance strikes the eye and from it alcohol rushes into your reason. When you see a trail - think of a hare; when the subject becomes dumb - philosophize where it leads; when you look at a portrait, remember the king; when you look in the mirror - remember your dummy - it is behind you, and you are only seeing its shadow."17 The parables are exactly a mirror revealing the truth, "But these talks are the same as that mirror."18 Fables which Skovoroda often inserts into his narrative, are close to the genre of parables. If proverbs were mostly adopted from the Bible, Skovoroda composes fables himself or borrows them from his book, "Kharkov Fables."

The dialogues of Skovoroda contain the basic features of the dialogue of a catechetical type - the authoritarianism of truth and those characters who proclaim it, didacticism, incompleteness of compositional structure, one-dimensionality of characters, reticence of details, esoteric perception of truth by the neophytes, and apriorism of truth. There is no need to seek the truth in a dialogue, for it has already been given; it is only necessary to proclaim it and to bear testimony to it.

Considering the healing of the soul as his mission and making the diagnoses-aphorisms, Skovoroda treats his listeners with doses of sacred texts. The main remedy, or rather the entire pharmacy is certainly the Bible. "Now I will say: read the Bible, in the discerning of needs it

(16) Сковорода, Сочинения, т. 2, с. 149.

(17) Ibid., т. 1, c. 272.

(18) Ibid., c. 270. 
is the pharmacy acquired through God's wisdom for healing the peace of the soul, which cannot be healed by any earthly medicine." ${ }^{19}$ Skovoroda inherited the edifying and ornate character of his style from the parables, and he took the imagery of his language from the Bible. We should, however, note that Skovoroda constantly mixes up using the Bible as a source of images, parables, and examples, and as a model for philosophizing, which it is ultimately not.

Already in his relation to the Bible and his understanding of the Bible we may find the basic principles embedded in the philosophy of the Ukrainian sage. It is in the Scripture that Skovoroda sees the main subjects for his philosophizing, "The whole Bible breathes with this taste: 'Know thyself,'"' ${ }^{20}$ etc. Understanding of the Bible is difficult, "The whole Bible is a knot and a chain of knots." 21 This knotted entanglement of understanding stems from the fact that the sacred text does not have a single meaning; it is made up of images, the understanding of which requires a special interpretative procedure and interpretive technique. "It seems to me that the Bible itself was created by God from sacredly mysterious images: the sky, the moon, the sun, the stars, the night, the morning, clouds, the rainbow, paradise, birds, animals, man and so on." ${ }^{22}$ However, "the whole Bible is filled with chasms and temptations." 23 The danger lies in the literal understanding of the sacred text. This understanding gives rise to superstitions which, in the opinion of the philosopher, are worse than atheism..$^{24}$ Skovoroda contrasts allegorical interpretation with superstitious or literal understanding of the Bible. "The Bible is a lie, and the foolishness of God (cf. 1 Cor 1:21) is not that the Bible would teach us a lie, but that it would imprint the tracks and paths in a lie, which would lead the crawling mind up to the supreme truth." ${ }^{25}$ Allegory is the basis of symbolic understanding. Skovoroda sees the elements of literal, that is, external, outward, and superficial understanding of faith in Church rituals. Skovoroda's criticism of the belief in sufficiency of following rituals and of official Church religiosity was based exactly on his demand for

(19) Сковорода, Сочинения, т. 1, с. 367.

(20) Ibid., c. 415.

(21) Ibid., c. 408.

(22) Ibid., c. 415.

(23) Ibid., т. 2, c. 38.

(24) Ibid., c. 17.

(25) Ibid., c. 10. 
the symbolic understanding of religious truth and the inner direct communication with the deity. In particular, his rejection of monasticism was based both on the rejection of the ritualistic, decorative part of this institution, and on the recognition of its uselessness, usefulness and irrelevance. "To acquire a strange and masquerade habit, to stray to the Nytrian mountains, to live among howling wolves and snakes - is it not a burden? Sure! Grievous because it is silly and needless." ${ }^{26}$

Skovoroda explains that sacred texts contain multiple layers of meaning because "in the Bible one thing is on the face and another thing is in the heart. <...> Noble and amusing is this deception and fraud, where we find truth underneath falsehood, wisdom underneath foolishness, and in the flesh - God." ${ }^{27}$ The Bible calls for symbolic interpretation which is explained by Skovoroda in the following way, "It borrows words from you signifying your base circumvolution, for example, legs, arms, eyes, ears, head, clothes, bread, vessels, house, soil, livestock, land, water, air, fire. Yet it never walks around the circle, but strikes at the very finest and most important point for the entire encirclement, to which it had exclusively intended to bring you. It only speaks with your words, but not of yours. $<\ldots>$ This is the same thing - to lead you up from your earthly dirt and your outward externals to the very immaterial and indivisible point which comprises your entire being and core, up to the height about which the Wisdom itself deigns to say, 'For whoever finds me, finds life."' 28 The way and method for the human to know himself is the same as the method of symbolic interpretation of the Scripture. Biblical exegesis acts as the model of cognition of existing things and man.

The desire to see the hidden intent, the secret and simultaneously the most important meaning in the Biblical allegory was not discovered by Skovoroda. It has a long history going back to the development of the method for allegorical interpretation of the Bible in the second-third century Alexandrian exegetical school. ${ }^{29}$ Skovoroda learned this and similar principles and actively used them in his works. We

(26) Сковорода, Сочинения, т. 1, с. 260-261.

(27) Ibid., т. 2, c. 33.

(28) Ibid., T. 1, c. 219.

(29) See Origen, De principiis, IV, 20; IV, 23. On Origen's method of allegorical interpretation see R. P. C. Hanson, Allegory and Event. A Study in the Sources and Significance of Origen's Interpretation of Scripture, Richmond, 1959; E. A. Dively Lauro, The Soul and Spirit of Scripture within Origen's Exegesis (The Bible in Ancient Christianity, 3), Leiden, 2005. 
cannot say that the need for symbolic interpretation was obvious for Skovoroda; he attempted to justify and validate such an understanding of the Scripture and the world. However, symbolic interpretation was merely a methodological point of his work whose goal was to proclaim a certain moral ideal. Skovoroda did not consider the method from a theoretical viewpoint; he actively used symbolic interpretation but spoke about its principles only in passing.

Skovoroda belonged to a tradition with well-developed and detailed procedures for symbolic or allegorical interpretation. According to Shpet, "The essence of the so-called allegorical interpretation is usually seen in allowing for a different sense, accessible not to all people and not at all times, deeper (hyponoia) and, for the most part, mystical, in addition to the direct sense of the words under interpretation, accessible to all. Yet, if we turn to the representatives of this trend, we will see that, in fact, for the most part, along with the direct sense they allow not for one deeper sense, but for two, three or more." ${ }^{30}$ Skovoroda did not trouble himself with identifying multiple meanings of the sacred text, but only followed the general principles of allegorism. By itself, this method was an auxiliary subject of theology, and was a phenomenon of medieval culture, mainly used by the representatives of the religious-oriented consciousness. "Medieval allegory relies, as a rule, only on Biblical texts, on the word of God, which has a deeper meaning. Its primary literal meaning (sensus litteralis) remains. And it is this meaning which is the starting point for the consequent spiritual allegorical interpretation. Therefore, we cannot speak about allegory here, but about the process of allegorizing." ${ }^{31}$ Zeeman distinguished four techniques of medieval allegorizing: 1) allegorism, 2) typology, 3) etymology of words, especially, names, 4) syncrisis. ${ }^{32}$ All of them can be found in the works of Skovoroda. We should say that Skovoroda was not the most prominent representative of the allegorical method of interpretation. The rules of symbolic interpretation of the Bible had been expounded in Russia before, and in greater detail, for example in the book of sermons by Ioannicius Galyatovsky (1659). Simeon of

(30) Г. Г. ШпЕт, “Герменевтика и ее проблемы” [Hermeneutics and its Problems], in Контекст-1989, Москва, 1989, с. 234.

(31) К. Д. ЗЕЕмАН, “Аллегорическое и экзегетическое толкование в литературе Киевской Руси" [Allegorical and Exegetical Interpretation in Kievan Rus], in Контекст-90. Аитературно-теоретические исследования [Cопtext-90. Literary and Theoretical Studies], Москва, 1990, с. 73.

(32) Ibid. 
Polotsk (1629-1680) used more sophisticated and more developed exegetical techniques for revealing the four-fold meaning of the Scripture (which goes back to the ideas of Augustine). Allegorical and typological exegesis was widespread in Kievan Rus, and its greatest representative was Cyril of Turov (ca. 1130 - ca. 1182). In the Old Russian tradition, the terms "image" and "prototype" were the equivalents of the allegorical meaning. ${ }^{33}$

The need for symbolic interpretation is not simply built into the structure of the Bible, thus, representing the technical aspects of working with the text. Apart from the psychological effect that, according to Clement of Alexandria, "all things which shine through a veil show the greater and more majestic truth," 34 this necessity is safeguarded by the divine world order. Vladimir Ern pointed to the fact that Skovoroda ascribed an ontological status to the symbolic method as a consequence of its deification, "Similarity and the symbolic nature of the world are rooted in God himself and have therefore an ontologically objective, rather than a human and subjective nature." 35 The deepest meaning of life is related to divine authority. "And all these traces whether they are written or uttered in it, will be fulfilled by the Lord, that is to say, the truth of the Lord will endow non-existing creatures with end and being. This is what 'From God all things are possible' means, that is to say, it is empty and insufficient according to the creatures and it is real and accurate according to God." ${ }^{36}$ The investigation of this meaning requires an unconditional and unmediated connection with supernatural reality. Yet this way to being is not transcendence. The interpreter of divine truths, reading them behind the symbolic structure of the books of the Scripture or the Book of Nature, is not a philosopher; he is a prophet. "This is what it means to be a prophet or a philosopher, to see something new, ever-young, wonderful and eternal beyond the desert, beyond the elemental enmity, and to declare it." ${ }^{37}$ To be not a researcher but a herald, a trumpet of the truth - that is now a function of the philosopher who is transformed into a prophet, "The name is the same - prophet or philosopher." ${ }^{38}$ The prophetic status of phi-

(33) ЗЕемАН, “Алиегорическое и экзегетическое толкование,” с. 76.

(34) Clement of Alexandria, Stromata, V, 9, 56.5.

(35) Эрн, Григорий Саввич Сковорода, с. 233.

(36) Сковорода, Сочинения, т. 2, с. 11.

(37) Ibid., т. 1, с. 362.

(38) Ibid., c. 277. 
losophy, however, does not transform its adherents to magicians and exorcists of being. A philosopher becomes only a promoter and propagator of moral maxims pointing the way to the blessed life. Everyday life morality lies at the symbolic depths of divinely inspired texts.

However, Skovoroda makes no distinction between the truth and meaning when he turns to the interpretation of the text. The interpretation does not reveal the truth, but produces the sense. Sense is the effect of interpretation. It is difficult to discern the philosophical meaning behind a host of biblical passages. Their polisemantism by itself is not a warranty of philosophical content. The shimmering nature of meaning may help here. Meaning is not monosemantic, therefore, it could be discovered in almost everything which is subject to interpretation. Meaning is a product of speech; it "lives" in the language and is not the subject of a thing, de re. The thing acquires semantic certainty in a proposition, and existence acquires certainty in a thought. The articulated world is potentially meaningful, and the semantic potentiality is realized in interpretation. Interpretation is the reality of meaning. Skovoroda puts in the form of concise aphorisms the meaning that he intends to express directly, without the veils of Biblical citations. These aphorisms condense Skovoroda's thoughts which do not receive further speculative development. The thought of Skovoroda is discrete and point-like, showing a different culture of thought, different intellectual practice, and the prevalence of figures of speech over figures of thought. Truth is simple, easy and obvious, yet it is accessible only to the elect. Truth has a mystical character; there is no need to give it detailed substantiation and to carefully prove it. Truth is substantiated not through multi-level syllogism, but through personal experience (as practical wisdom) and direct discerning (as a mystical experience). The interpretation is needed not for the truth, but for the meaning produced by the truth.

Symbolical interpretation in a simplified form which can be found in Skovoroda's writings identifies two levels of text: the literal level, directly related to what is narrated, and the figurative level - the symbolic or semantic level in the proper sense. Identification of the semantic level is the goal of symbolic interpretation. Interpretation of the world following a similar scenario as well identifies two levels of existence: the direct external level, and hidden semantic level. Therefore, the meaning generated by the interpretation is built on the antinomy of the two worlds or two layers of existence and text as well as on the antinomian identification of the two aspects of any image: visible and 
invisible, true and corruptible. The nature of this meaning is illusory in the same way as transcendental antithetics are illusory. Furthermore, the symbolic meaning produced by interpretation is not neutral. It does not hang between the worlds; it does not get stuck between the doors of the image, but points to the "otherworldly" homeland of everything ideal. Meaning is illusory, but this is the illusion expressing the truth. It should be noted that the expression of the truth on the face of meaning is more important and more noticeable than the truth itself with which its twin, its reflection in the face of the semantic cloud, may not at all coincide. Meaning is the imitation of truth. The same is the final effect and the result of interpretation - to depict, to simulate the truth in an intelligible (semantic) form.

Among the forerunners of the symbolic method and his predecessors in the philosophical field, Skovoroda names the "ancient sages" and, in particular, refers to the book of Cicero, On Old Age. He accompanied this reference with the following philological argument, "The image that contained a mystery was named in Greek $\check{\varepsilon} \mu \beta \lambda \eta \mu \alpha$, emblema, that is to say, vkidka [lit. "throwing in,"], vpravka [insertion, reset] $<\ldots>$ And if we put together two or three of these figures, as in the aforementioned seal [Skovoroda speaks about the seal of the Emperor Augustus - A. M.], then it was called $\sigma u ́ \mu \beta o \lambda o v$, conjectura in Latin, in our language it would be skidka [lit. "throwing together"], smetka [lit. "casting together]." ${ }^{39}$ These observations Skovoroda directly used for developing his own symbolic language of meaning and for interpreting specific images. Such allegorical interpretations, in his opinion, constitute the essence of theology, "Fabulous books of the ancient sages are that very same most ancient theology. They also portrayed the immaterial substance of God with perishable figures to make the invisible visible, represented by the figures of creatures." ${ }^{40}$ According to Skovoroda, in this way one may assure the demonstrativeness which leads directly to understanding. However, the demonstrativeness for him is not a theoretically attainable conspicuity, but the result of the impact of examples and illustrations.

Thus, the method of symbolic interpretation has Biblical roots. According to Skovoroda, "This varied intertwinement of images and figurative knots are named signs and wonders in the Bible." 41 Yet the scope

(39) Сковорода, Сочинения, т. 1, с. 374.

(40) Ibid., c. 457.

(41) Ibid., c. 384. 
of this method is much broader; all creation has a symbolic depth, a semantic lining, embedded by the Creator. The emergence of semantic entrails is one of the consequences and, at the same time, characteristics of the creation: "So, if you want to learn something in the spirit or in truth, observe the flesh, that is to say, the appearance, and you will see the traces which are being imprinted by God, exposing His innermost and secret wisdom (Ps. 51:6) and leading to it as if through a footpath." ${ }^{42}$ Being assured in the meaning during the process of interpretation, we approach God and go over to the realm of faith.

The appeal to God in this case is not ungrounded. Divine authority is the total space of meaning, the training ground of interpretations. God does not have anything meaningless. Any name not only bears sense; the sense is immediately cast in elastic, material, wholesome substance. Every name is warranted by matter. Substantial supply of divine power is inexhaustible. Minting names, God immediately casts them into things: "Among the mortals, a name is often given to those things which do not possess the substance of the name. It is not the same with God. In God name and substance are identical; as soon as He gives the name, He gives the nature." ${ }^{43}$ God thinks and speaks with things and events. Each object is both the word of God and the event of God. "Giving birth, God infuses substance, power, and nature, and in so doing gives the name." ${ }^{44}$ In the word of God, substance and existence coincide and are identical. The word directly goes over to being and is cast with semantic definiteness - the subject. The world appears as an explanation of the supreme being whose letters hide the truth. Yet, the search for truth is not an experiment; it is interpretation where the meaning may hit the truth, but may also miss it. The discrepancy between the substance and the existence, the truth and the meaning in the human language is the result of the imperfection in human judgment (the historical source of which was the Fall) which distinguishes between the word and the object which is designated by this word. Skovoroda insists, "Our lie divides between to be and to be named, and not the divine indivisible truth." 45

Divine creative language does not have the problem of the signified. This problem cannot appear in another ideal language - the

(42) СковородА, Сочинения, т. 1, с. 301.

(43) Ibid., c. 448.

(44) Ibid., c. 449.

(45) Ibid., c. 448. 
Adamic language (lingua adamica), filled with meaning. The semantic reserves of the Adamic language directly pour on the silent world of objects, first expressing the substances with names, naming the world and all beings, leaving not a hole for error, not a gap for semantic miss. Inflation in substance occurs only in the ideal of a universal language, and with it the opportunity for lies, mistakes, or delusion. However, Skovoroda did not intend to correct the imperfection of the human language and understanding to the measure of the universal language; he did not intend to re-register the compartments of the world and language. He had a simpler goal - to bring back to word to what the word meant, "One thing is to understand the name, and another thing is to understand what is signified by the name." ${ }^{\prime 6}$ The primacy of the signified is based on its semantic authority and priority. The signified rules the language; it directs semantic flows, and distributes the meanings, "There is no great need to know how this word was born: khleb ["bread"] from khleb or from khlopoty ["chores"], but the power is only in what is meant though this name." ${ }^{47}$ However, this practice cannot correct the situation or cure the language. It only has a point impact and a concrete usage; it heals only some sections, conciliates word and being only in a particular passage, resets the language ${ }^{48}$ in the world only in a limited area. The name of the medicine is symbolic exegesis.

The correcting semantic optics which, through interpretation, allows for seeing the meaning that pretends to be truth, follows the principle, "to understand is to see beyond the visible object with your mind something invisible, promised by the visible." ${ }^{49}$ This is exactly what it means to interpret "not the name, but the thing." ${ }^{50}$ Interpretation therapy is, first of all, to isolate the outer literal shell of an event. Using the metaphor of the cud-chewing animal, Skovoroda expressed this as follows, "The first chewing is to sort out historical, ceremonial, parabolic, or, in one word, carnal rind or husk." ${ }^{51}$ And then adds by way

(46) Сковорода, Сочинения, т. 1, с. 246.

(47) Ibid., c. 318.

(48) I should remind the reader that Skovoroda translates the word "emblema" as insertion or reset; his method is to eliminate a semantic dislocation (cf. Ibid., c. 374; т. 2, c. 23).

(49) Ibid., c. 281.

(50) Ibid., c. 246.

(51) Ibid., c. 209. 
of introspective digression, "Chew yourself more strongly!"52 Deep penetrating interpretation reveals that, "Thus, here the shadow is instead of the body, the sign is instead of the thing." ${ }^{53}$ Words themselves become cheaper and drop in value, "A term or a word is sackcloth!" 54 The interpreter as a surgeon separates the coverings from the interior parts, dissects the tissues in order to sew them in a new style according to an adequate semantic size. An approximate result of the healing is as follows, "If the outgoings of wisdom are the outgoings of life, it is clear that the going out from Egypt means to go out from death to life, from knowledge to knowledge, from strength to strength until the God of gods will show himself in Zion." ${ }^{55}$

Semantic probing leads to the state that "the entire outward appearance of your body is nothing else but your mask covering each of your members according to genus and likeness, hidden in your heart as if in a seed." 56 Skovoroda very much likes to use various elements of the theater metaphor, such as masks or decorations. In a similar way he represents, for example, the monks, "This is only one monastic masquerade." ${ }^{57}$ The same is also the surrounding world, "This is the shade and mask." ${ }^{58}$ Yet, if we think about it, the etymological or rather the semantic outlines of the term "mask" are quite interesting. Masks (Lat. "personae") were used in comedies or tragedies to represent individual characters, and to separate them from each other. The negative shade of meaning which Skovoroda attaches to the word "mask," reveals his rejection of individual, separate, singular existence. His criticism of the illusory nature of the world in theatric terms hides his denial of concrete, definite existence, which became embodied in a semantic image. In a formal manner, in his works and directly in his life Skovoroda avoids definiteness, eschews consistency and steadiness, evading to ambiguous symbolism, hiding behind the polysemy of figurative language.

(52) СковородА, Сочинения, т. 2, с. 215.

(53) Ibid., c. 241.

(54) Ibid., c. 173. Cf. Ps. 83:8 of the Slavonic (Septuagint) version (Ps. 83:8 of the King James version).

(55) Ibid., т. 1, c. 224.

(56) Ibid., c. 222.

(57) Ibid., c. 260.

(58) Ibid. 
Symbolic language is not a new language (compared to the literal), but fitting, tailoring of the language to a different (in this case divine = true) reality. Symbolic language is the detailed morphological development of the old language, its supplementation, completion to the "genuine" reality. Skovoroda did not specifically develop the morphology symbolic interpretation; his remarks on this subject are fragmentary and accidental. We cited above his understanding of symbol, containing ancient allusions. This interpretation of symbol and symbolism can be supplemented by the following considerations. First of all, symbols are not of equal value. Skovoroda established a hierarchy of symbols, according to which there existed the basic symbols called archetypes. Skovoroda also called them original or main figures. Antitypes which Skovoroda also called prototypes, vice-images, vicefigures, or copies, can also be considered the basic symbols. ${ }^{59}$ An antitype depends on the archetypes which may result from disassembling

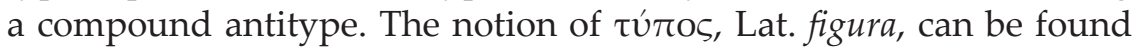
in Apostle Paul (Rom 5:14), where it represents the events of the Old Testament acting as "prefigurations of things to come." ${ }^{60}$ Although symbol represents "figurative deadness," ${ }^{161}$ it is a figure of understanding, only half of which is known or discernible. The second half of the symbol is related to the unknown, the mystery. The key to deciphering this mystery is in the first half of the symbol. In an old-fashioned manner Skovoroda puts it as follows, "To cherish this, to observe, to notice: this means to understand the unknown with the known, and to throw an intellectual beam from the forthcoming as if from a high mountain like a well-aimed arrow into a remote mystery. From this the word symbol originates." ${ }^{62}$ The process of deciphering - interpretation - is the transition from the manifest to the hidden, from the known to the unknown and, therefore, is a way of learning. In this sense, all knowledge is symbolic.

Like a semantic construction set, the method of symbolic interpretation allows for further disassembling, dismembering, and fragmentation of symbol. "Symbol is made up of two or three figures, meaning corruption and eternity <...> For example, evening and morning, water,

(59) Сковорода, Сочинения, т. 2, с. 153.

(60) ЗЕЕМАН, “Алиегорическое и экзегетическое толкование," с. 77.

(61) СковородА, Сочинения, т. 2, с. 23.

(62) Ibid., T. 1, c. 281. 
solid ground, and cloud, sea and land." ${ }^{63}$ As can be seen, symbol has several components which produce a cross-referenced, multilayered meaning, that is to say, symbolic meaning (although, perhaps, every meaning is partially or potentially symbolic, at least, it is not unambiguous since it has a mediated relation to reality). The figures which make out the symbol are relatively simple, yet they are not originally literal. The symbol has an antinomic nature; its semantic flows move in different directions. The opposite, mutually repelling, but at the same time complementary meanings are combined, compared, and superimposed in the symbol. The essence of the method of symbolic interpretation is such semantic dissection. "To divide and to solve means the same," succinctly states Skovoroda. ${ }^{64}$

However, the morphology of symbolic interpretation does not end here; and symbolic dissection continues. Skovoroda called images the figures which composed the symbol. ${ }^{65}$ Images were already observable and material. "Every appearance is image, and every image is flesh, shadow, idol and nothing." ${ }^{66}$ Despite its insignificance, the image is relevant to a specific material reality. Yet, the image, in turn, can be as well decomposed into three components. Not going into details or further elaborating on the subject, Skovoroda puts it as follows, "Upon consideration each representation is three, that which is simple, representing, and represented." ${ }^{67}$ Given that image pertains to the specific reality of objects and events, we may say that the understanding of image in the context of Skovoroda's method of symbolic interpretation is the analytic identification of the tripartite structure: that which the event or the object included in the image represents by itself (the literal interpretation), then figurative or allegorical understanding, that is, their understanding as such objects or events which represent something different than what they are, and finally, this different takes the form of a new, figurative and allegorical meaning. Symbolic interpretation, therefore, constitutes the transition from the material and literal understanding (often simply identical with perception) of objects and events to an allegorical, in the proper sense transitional understanding, awakening a new, non-literal sense. It should be noted that this
(63) СковородА, Сочинения, т. 2, с. 21.
(64) Ibid., т. 1, c. 410.
(65) Ibid., c. 374.
(66) Ibid., c. 383.
(67) Ibid., c. 409. 
transition is not substantial, since symbolic interpretation refuses to see an object or event as a substance, thereby removing a substantial prop of selfness, sameness, and identity of the object. The object becomes pliable and more suitable for modeling and fabrication. That what the object is, its selfness, is being removed. Symbolization is set against definition when the essence appears as selfness, as a specific what. Skovoroda almost nowhere gives definitions, avoiding them at all costs. Substance, expressing what the object or event is in itself, forms the basis of the principle of individuation - the becoming of the object as semantic certainty. At the same time, substance connects the object with other objects of the same type, which makes it possible to express the substance in a definition as the principal "whatness." In the process of symbolic interpretation, the object or event is no longer understood as oúrí $\alpha$. The object loses its individuality and relationship to the genus. The object or event does not disappear and continue its existence. It only loses its substance, its what, instead of which gapes unbarren emptiness. The substance of the object or event is removed and its place can be taken over by any other form or substance imitating semantic image. Due to the symbolic interpretation, the object or event continues to exist, but it may take any semantic form, instead losing its intelligible nature. Instead of embodying the substance, symbolic interpretation provides a semantic appearance, turning the object into an image, a sign, an icon. In short, in the structure of symbolic interpretation, image combines its direct relationship to reality and the possibility of a literal reading with semantic imitation.

Achieving symbolic reality, the arrangement and development of the world with symbolic language does not say anything both about the substance and about the truth. New language structure and its symbolic stories do not lead to the truth. Truth in this case does not have a constructive nature, but is revealed through the correspondence of symbolic moves, generated by interpretation, with the semantic level of reality. These moves are also not the paths of thinking. Truth and thought in the tradition followed by Skovoroda are of different nature. We should note again that strictly speaking, Skovoroda does not have an articulated concept of symbolic interpretation. In fact, his whole philosophical thought is not concept-oriented, if we understand the concept as expression of thought and embodiment of what is hidden behind the thought, the idea. Skovoroda did not express the practice of symbolic interpretation in terms of a problem-solution approach. Thought for Skovoroda has another status; it comes not from sub- 
stance (and, accordingly, is not focused on definitions), but from will, therefore, becoming arbitrary.

Between the thought and desire there should be something that allows thought to dominate the passions of the soul. The capacity of thought to dominate the passions is caused by the fact that thought is a kind of desire, longing, or urge. In this case one desire inhibits and displaces another desire. Skovoroda thus describes thought in his Dialogue, "Conversation among five travelers about life's true happiness": "Ceaseless aspiration for it is the desire." 68 We should draw attention to the dynamic, mobile, eager nature of thought. Skovoroda offers another figurative understanding of thought. Thought travels, "as if on journey, it looks for its affinity among dead elements..." ${ }^{69}$ The travel of the thought as a search and transfer according to the affinity or likeness is a reference to Aristotle's classical definition of metaphor. ${ }^{70}$ Although Skovoroda insists that the wandering of thought stops when a person turns to himself or to the Bible, we still focus our attention on impermanence and instability of thought. Steadiness is the ability of beings to exist in a specific way - to correspond to their substances. Thought, however, has nothing to do with the formation of being, as it may seem at the beginning.

Differentiation between the actual existence and thought is the differentiation between substantial and under-substantial entities. In this sense, the supremacy of thought is determined by its preliminary nature, its dynamics, its potentiality preceding that which has become an actual being, an embodied substance. The supremacy of thought is process-oriented; the thought is closer to the "beginning," but it is not perfect, not accomplished, not embodied into event and therefore ontologically defective. "Thought is the invisible chief of the tongue, the seed of the deed, the root of the body. Thought is the incessant tongue, unremitting spring, ceaseless movement, moving and carrying upon itself, like a time-worn robe, corruptible and fleshly dirt clinging to the thought and disappearing like a shadow under an apple tree." ${ }^{71}$ Thought is expressed through a set of metaphorical statements which preserve the traces of the image, and is represented in relation to language, deed, and body as the internal in relation to the external, the

(68) СковородА, Сочинения, т. 2, с. 341.

(69) Ibid., c. 342.

(70) Cf. Aristotle, Poetics, 21, 1457b.

(71) СковородА, Сочинения, т. 2, с. 435. 
invisible in relation to the visible, that which moves in relation to that which is moved. Characteristics of motion predominate. Another attribute of thought which may be found in the above passage, highlights the thought as something unrevealed and invisible, as a possibility, as something not completely embodied, as something that can take any shape and is perceived as an image. This image expresses and reveals the unfinished and deficient substance which has not yet become the entelechy, in the horizon of the present existence. The thought is the dynamic force of possibility. The act of thought creates its subject. However, full-fledged creation remains within God's cognizance and divine language. Summarizing the thought of Skovoroda, Mikhail Kovalinsky noted that divine will or wish is the basis of creation. ${ }^{72}$ The voluntarism of Skovoroda's thought is the result of his general theological attitude. Vladimir Ern insightfully noted that "The thought of Skovoroda is so voluntaristic that he conceives the essence of the entire Christian theology as a specific concept of will."73 The consequences of voluntarism, connected with the symbolic method appear in almost every writing of Skovoroda, and determine many substantive points of his work so that "in general, he subordinates rational points to the symbolic principle, and not the other way around." ${ }^{74}$

\section{SUMMARY}

This article describes the religious and philosophical teaching of the Russian-Ukrainian thinker, Grigory Savich Skovoroda (1722-1794). Skovoroda wrote his major philosophical works in the last twenty-five years of his life. These writings show him primarily as a religious thinker who continues the tradition of the Kiev-Mohyla Academy, in particular, the tradition of medieval exegesis following the allegorical method of interpreting sacred texts.

(72) КовалинСКий, “Жизнь Григория Сковороды,” т. 2, с. 392.

(73) Эрн, Григорий Саввич Сковорода, с. 85.

(74) Ibid., c. 223. 